\title{
Pengaruh Return On Equity (ROE), Debt To Assets Ratio (DAR), Price To Book Value (PBV) Dan Net Profit Margin (NPM) Terhadap Return Saham Perusahaan Sektor Perkebunan Yang Terdaftar Di Bursa Efek Indonesia Periode 2011-2017
}

\author{
Mochammad Ridwan Ristyawan* \\ Fakultas Ekonomi dan Bisnis, Universitas Tanjungpura, Indonesia
}

\begin{abstract}
The financial condition of the plantation companies listed in the Indonesia Stock Exchange during 2011-2017 shows that the company has high asset value. The stock return of companies is experiencing a fluctuating condition. The sample in this study was taken using purposive sampling technique so that obtained 8 research samples. The data analysis tool used in this study is quantitative analysis. The results of the study are as follows: 1) Return on Equity (ROE) has significantly negatif effect on stock returns, 2) Debt to Assets Ratio (DAR) has not significantly positive effect on stock returns, 3) Price to Book Value (PBV) has significantly positive effect on stock returns, 4) Net Profit Margin (NPM) has not significantly positive effect on stock returns. In this study the ratio of PBV, and NPM proved to have no significant effect on stock returns, while ROE and DAR had a significant but opposite direction.
\end{abstract}

JEL : G14, G32

Keywords : plantation sector. financial ratios. stock returns

\section{PENDAHULUAN}

Kondisi keuangan perusahaan sektor perkebunan yang terdaftar di Bursa Efek Indonesia selama 2011-2017 menunjukkan perusahaan mempunyak tren nilai aktiva naik sementara return saham perusahaan-perusahaan tersebut justru mengalami kondisi yang cenderung fluktuatif. Nilai aktiva perusahaan yang ditunjukkan pada Tabel 1 menggambarkan aktiva perusahaan perkebunan mengalami kenaikan dari Tahun 2011 sampai 2017. Perusahaan-perusahaan mengalami peningkatan dan penurunan return saham yang ekstrim yang ditunjukkan pada Tabel 2 seperti saham Astra Agro Lestari Tbk (AALI) secara rata-rata mempunyai return negatif. "Return dari saham banyak dipengaruhi dari berbagai informasi mengenai suatu perusahaan baik bersifat teknikal maupun fundamental" (Sari, 2016).

Investor dalam menentukan pilihan untuk menanamkan sahamnya dengan mempertimbangkan satu perusahaan dengan perusahaan lainnya. Aliran modal masuk dan keluar dalam bentuk saham sering terjadi di perusahaan-perusahaan agribisnis dan faktor risiko gagal

"Email : m.ridwanristyawan@untan.ac.id Received: 06-08-2018, Accepted: 06-11-2018, Published : 29-04-2019

P-ISSN : 2087-9954, E-ISSN : 2550-0066. DOI : http://dx.doi.org/10.26418/jebik.v8vi1.26966 
panen akibat perubahan cuaca dan iklim menjadi pertimbangan (Djokoto, Srofenyoh, \& Gidiglo, 2014; Nunoo \& Acheampong, 2014). Return saham merupakan tujuan utama dari aktivitas perdagangan yang ingin dicapai oleh semua investor yang akan menanamkan sahamnya pada pasar modal. Return saham juga memungkinkan untuk investor dalam membandingkan tingkat pengembalian satu perusahaan dengan perusahaan lainnya (Hartono, 2014).

Tabel 1. Aktiva Sampel Perusahaan Perkebunan Tahun 2011-2017

\begin{tabular}{rrrrrrrr}
\hline \multirow{2}{*}{ Nama } & \multicolumn{7}{c}{ Aktiva (dalam jutaan rupiah) } \\
\cline { 2 - 8 } & $\mathbf{2 0 1 1}$ & \multicolumn{1}{c|}{$\mathbf{2 0 1 2}$} & $\mathbf{2 0 1 3}$ & $\mathbf{2 0 1 4}$ & $\mathbf{2 0 1 5}$ & $\mathbf{2 0 1 6}$ & \multicolumn{1}{c}{$\mathbf{2 0 1 7}$} \\
\hline AALI & 10.204 .495 & 12.419 .820 & 14.964 .431 & 18.588 .329 & 21.512 .371 & 24.226 .122 & 24.955 .398 \\
\hline BWPT & 3.589 .031 & 4.913 .000 & 7.021 .492 & 16.379 .840 & 17.658 .837 & 16.254 .353 & 15.854 .114 \\
\hline GZCO & 2.834 .598 & 3.187 .521 & 3.201 .105 & 3.232 .644 & 4.964 .076 & 3.547 .023 & 2.837 .715 \\
\hline LSIP & 6.791 .859 & 7.551 .796 & 7.974 .876 & 8.655 .146 & 8.848 .792 & 9.459 .088 & 9.786 .628 \\
\hline SGRO & 3.411 .026 & 4.137 .700 & 4.512 .656 & 5.466 .874 & 7.294 .673 & 8.328 .480 & 8.204 .967 \\
\hline SMAR & 14.722 .000 & 16.247 .000 & 18.381 .114 & 21.292 .993 & 23.957 .015 & 26.141 .410 & 25.720 .056 \\
\hline TBLA & 4.244 .618 & 5.197 .552 & 6.212 .359 & 7.328 .419 & 9.283 .775 & 12.596 .824 & 14.030 .169 \\
\hline UNSP & 18.702 .295 & 18.983 .332 & 18.015 .337 & 17.441 .633 & 16.926 .617 & 14.700 .318 & 14.389 .576 \\
\hline
\end{tabular}

Sumber: BEI, (2018)

Tabel 2. Return Saham Sampel Perusahaan Perkebunan Tahun 2011-2017

\begin{tabular}{crrrrrrr}
\hline \multirow{2}{*}{ Nama } & $\mathbf{2 0 1 1}$ & $\mathbf{2 0 1 2}$ & $\mathbf{2 0 1 3}$ & $\mathbf{2 0 1 4}$ & $\mathbf{2 0 1 5}$ & $\mathbf{2 0 1 6}$ & $\mathbf{2 0 1 7}$ \\
\cline { 2 - 8 } AALI & $-17,18 \%$ & $-9,22 \%$ & $27,41 \%$ & $-3,39 \%$ & $-34,64 \%$ & $5,84 \%$ & $-21,61 \%$ \\
\hline BWPT & $-18,98 \%$ & $57,66 \%$ & $-24,00 \%$ & $-69,92 \%$ & $-65,50 \%$ & $98,55 \%$ & $-33,21 \%$ \\
\hline GZCO & $-40,70 \%$ & $-21,57 \%$ & $-45,00 \%$ & $22,73 \%$ & $-29,63 \%$ & $-21,05 \%$ & $-13,33 \%$ \\
\hline LSIP & $-82,49 \%$ & $2,22 \%$ & $-16,09 \%$ & $-2,07 \%$ & $-30,16 \%$ & $31,82 \%$ & $-18,39 \%$ \\
\hline SGRO & $-8,66 \%$ & $-15,52 \%$ & $-18,37 \%$ & $5,00 \%$ & $-19,05 \%$ & $12,35 \%$ & $34,55 \%$ \\
\hline SMAR & $28,00 \%$ & $2,34 \%$ & $19,85 \%$ & $3,18 \%$ & $-48,15 \%$ & $3,57 \%$ & $-21,38 \%$ \\
\hline TBLA & $17,07 \%$ & $-4,17 \%$ & $2,17 \%$ & $60,64 \%$ & $-32,45 \%$ & $94,12 \%$ & $23,74 \%$ \\
\hline UNSP & $-26,92 \%$ & $-67,37 \%$ & $-46,24 \%$ & $0,00 \%$ & $0,00 \%$ & $0,00 \%$ & $226,00 \%$ \\
\hline SUnyyyyyy
\end{tabular}

Sumber: BEI, (2018)

Rasio keuangan yang digunakan untuk mengukur kinerja keuangan perusahaan terdiri atas rasio aktivitas, rasio solvabilitas atau leverage, rasio aktivitas, rasio profitabilitas, dan rasio pasar (Kamaludin \& Indriani, 2012). Rasio keuangan dirancang untuk membantu mengevaluasi laporan keuangan atau membantu mengidentifikasi kekuatan dan kelemahan keuangan perusahaan.

Pengukuran profitabilitas perusahaan perkebunan yang terdaftar di Bursa Efek Indonesia dalam penelitian ini menggunakan rasio Return On Equity (ROE) dan Net Profit Margin (NPM). ROE yang semakin tinggi menunjukkan kinerja perusahaan semakin baik dan berdampak pada meningkatnya harga saham perusahaan. ROE bukan pengukur return pemegang saham sebenarnya karena tidak memperhitungkan deviden dan capital gain untuk pemegang saham (Heniwati \& Yani, 2011). Rasio NPM yang semakin tinggi menunjukkan bahwa laba yang dihasilkan oleh perusahaan juga semakin besar, maka akan menarik minat investor untuk melakukan transaksi dengan perusahaan yang bersangkutan.

Pengukuran leverage perusahaan perkebunan yang terdaftar di Bursa Eek Indonesia dalam penelitian ini menggunakan rasio Debt to Asset Ratio (DAR) atau Debt Ratio. Semakin tinggi Debt to Assets Ratio (DAR), maka semakin besar risiko yang dihadapi. dan investor akan meminta tingkat keuntungan yang semakin tinggi. Rasio yang tinggi menunjukkan proporsi modal sendiri yang rendah untuk membiayai aktiva. 
Pengukuran rasio pasar dalam penelitian ini menggunakan rasio Price to Book Value (PBV). Semakin tinggi rasio Price to Book Value (PBV) yang menunjukkan semakin berhasil perusahaan menciptakan nilai bagi pemegang saham. Hal ini sesuai dengan Signaling Theory dimana dengan informasi yang diperoleh dari sinyal yang diberikan oleh perusahaan, investor akan mengetahui seberapa besar nilai perusahaan.

Berdasarkan uraian di atas. maka dirumuskan permasalahan penelitian yaitu pengaruh Return on Equity (ROE). Debt to Assets Ratio (DAR). Price to Book Value (PBV). dan Net Profit Margin (NPM) terhadap Return Saham Perusahaan Sektor Perkebunan yang Terdaftar di Bursa Efek Indonesia Periode 2011-2017”. Penelitian ini diharapkan dapat memberikan kontribusi terhadap perkembangan temuan empiris mengenai pengaruh Return on Equity (ROE). Debt to Assets Ratio (DAR). Price Book Value (PBV). dan Net Profit Margin (NPM) terhadap return saham. Hasil dari penelitian ini diharapkan dapat menjadi acuan atau referensi bagi pihak perusahaan sektor perkebunan untuk meningkatkan kinerja keuangan perusahaannya dalam rangka meningkatkan return saham perusahaan.

\section{KAJIAN LITERATUR}

\subsection{Return Saham}

Salah satu faktor yang memotivasi investor dalam kegiatan investasi adalah adanya return saham. yaitu imbalan atas keberanian investor untuk menanggung risiko atas investasi yang dilakukannya. Return saham adalah tingkat keuntungan yang dinikmati oleh pemodal atas suatu investasi yang dilakukannya sebagaimana yang dinyatakan oleh Hartono dalam Carlo (2014). Return saham adalah harapan dari investor dari dana yang diinvestasikan melalui saham. di mana hasilnya berupa yield dan capital gain (loss).

Tandelilin (2010) mengatakan bahwa return merupakan salah satu faktor yang memotivasi investor berinvestasi dan juga merupakan imbalan atas keberanian investor menanggung resiko atas investasi yang dilakukannya. Return yang digunakan dalam penelitian adalah return aktual yaitu perbedaan return pada waktu tertentu dengan return periode sebelum waktu tersebut.

Horne \& Wachowicz (2008) menyatakan bahwa return is income received on an investment plus any change in market price. usually expressed as a percentage of the beginning market price of the investment. Return menunjukkan keuntungan yang diperoleh dari investasi sebagai akibat perubahan harga investasi tersebut di pasar modal.

Return saham menurut Hartono (2014) dapat dihitung menggunakan formulasi return aktual yaitu pembagian selisih return dan harga penutupan saham pada periode sebelumnya. Selisih harga saham diperoleh dengan mengurangkan harga penutupan saham pada periode waktu terhadap harga penutupan saham pada periode sebelumnya.

Return saham bersifat volatile terhadap kejadian dan perubahan (Hobbs, Schaupp, \& Gingrich, 2016). Artikel ini menjelaskan bahwa returns saham sangat mudah dipengaruhi ole $h$ perubahan yang berdampak pada perusahaan seperti terorisme. Mollick \& Nguyen (2015) menyatakan bahwa return saham perusahaan sektor minyak dan gas dipengaruhi secara positif oleh fluktuasi harga minyak. Perubahan faktor harga menyebabkan return saham perusahaan berubah dengan cepat. 
D’Antoni \& Detre (2016) menyebutkan bahwa investor khawatir terhadap pengembalian portofolio investasi mereka ketika ekonomi sedang mengalami resesi, yang berdampak pada perusahaan agribisnis.

\subsection{Rasio Keuangan}

Salah satu cara yang terpenting untuk melihat kinerja manajemen adalah dari laporan keuangan yang telah disusun pada periode yang bersangkutan. Dengan menganalisis rasio keuangan dapat diketahui kelebihan dan kelemahan suatu perusahaan serta resiko yang akan dihadapi investor apabila memutuskan berinvestasi.

Kasmir (2010) menjelaskan rasio keuangan merupakan kegiatan membandingkan angkaangka yang ada dalam laporan keuangan dengan cara membagi satu angka dengan angka lainnya. Perbandingan dapat dilakukan antara satu komponen dengan komponen dalam satu laporan keuangan atau antarkomponen yang ada di antara laporan keuangan. Kemudian angka yang diperbandingkan dapat berupa angka-angka dalam satu periode maupun beberapa periode.

Horne \& Wachowicz (2008) menyatakan bahwa financial ratio is an index that relates two accounting numbers and is obtained by dividing one number by the other. Rasio keuangan adalah pembagian dua data keuangan yang membentuk suatu angka indeks berupa persentase sehingga digunakan untuk menunjukkan hubungan antara dua data tersebut.

Perbaikan ROE dapat dilakukan dengan mengetahui interkoneksi laporan laba rugi dan neraca dengan mengembangkan strategi-strategi potensial (Mishra, Harris, Erickson, Hallahan, \& Detre, 2012). Rasio profitability dapat diketahui melalui profit margin di dalam ROE.

Hubungan antara long-term debt ratio dan profitability adalah negatif. Namun, berdasarkan hasil penelitian bahwa hubungan antara total debt ratio dan profitability menghasilkan asosiasi positif yang signifikan (Abor, 2007).

Hasil penelitian menunjukkan hubungan antara book values dan earnings adalah relevan (Kadri, Aziz, \& Ibrahim, 2009). Besarnya book values dapat mempengaruhi capital gain suatu saham yang tercermin dari nilai return saham.

\subsection{Hipotesis}

Berdasarkan rumusan masalah di atas, maka dapat diajukan hipotesis sebagai berikut:

a. Pengaruh Return on Equity (ROE) Terhadap Return Saham

Return On Equity (ROE) digunakan untuk mengukur tingkat efektivitas perusahaan di dalam menghasilkan keuntungan dengan memanfaatkan modal yang dimiliki perusahaan. Rasio ini menunjukkan kemampuan perusahaan untuk menghasilkan laba bersih dengan menggunakan modal yang dimilikinya. Teori ini didukung oleh penelitian yang dilakukan oleh Affinanda (2015) menunjukkan bahwa ada pengaruh positif dan signifikan antara Return On Equity (ROE) terhadap return saham. Penelitian lain yang dilakukan oleh Erwin (2013) menunjukkan bahwa ROE berpengaruh positif dan signifikan terhadap return saham. Pada penelitian yang dilakukan oleh Beny \& Mendari (2011) ROE berpengaruh positif dan signifikan terhadap return saham. Berdasarkan penjelasan tersebut, maka hipotesis yang diajukan dalam penelitian ini adalah: 
$\mathbf{H}_{1}$ : Return on Equity (ROE) berpengaruh positif dan signifikan terhadap return saham perusahaan sektor perkebunan yang terdaftar di Bursa Efek Indonesia.

b. Pengaruh Debt to Assets Ratio (DAR) Terhadap Return Saham

Debt to Assets Ratio (DAR) merupakan ukuran yang dipakai dalam menganalisis laporan keuangan untuk memperlihatkan besarnya jaminan yang tersedia untuk kreditur. Semakin rendah debt ratio maka akan meningkatkan laba sehingga semakin besar jaminan kreditor untuk pengembalian atas pinjaman yang diberikan oleh pihak perusahaan (Hadi, 2015). Semakin tinggi Debt to Assets Ratio (DAR), maka semakin besar risiko yang dihadapi dan investor akan meminta tingkat keuntungan yang semakin tinggi. Teori ini didukung oleh penelitian yang dilakukan oleh Carolin (2014) yang menunjukkan bahwa DAR berpengaruh negatif dan tidak signifikan terhadap return saham sehingga direkomendasikan untuk menambah sampel dan sektor industri. Penelitian lain yang dilakukan oleh Santri (2012) menunjukkan bahwa DAR berpengaruh negatif dan signifikan terhadap return saham. Berdasarkan penjelasan tersebut, maka hipotesis yang diajukan dalam penelitian ini adalah:

$\mathbf{H}_{2}$ : Debt to Assets Ratio (DAR) berpengaruh negatif dan signifikan terhadap return saham perusahaan sektor perkebunan yang terdaftar di Bursa Efek Indonesia.

c. Pengaruh Price to Book Value (PBV) Terhadap Return Saham

Price to Book Value (PBV) merupakan rasio pasar (market ratio) yang digunakan untuk mengukur kinerja harga pasar saham terhadap nilai bukunya. Teori ini didukung oleh penelitian yang dilakukan oleh Putri (2012) yang menunjukkan bahwa PBV berpengaruh positif dan signifikan terhadap return saham. Penelitian lain yang dilakukan oleh Indriani (2014) menunjukkan bahwa PBV berpengaruh positif dan signifikan terhadap return saham. Pada penelitian yang dilakukan oleh Akbar \& Herianingrum (2015) menghasilkan temuan bahwa PBV berpengaruh positif dan signifikan terhadap return saham. Berdasarkan penjelasan tersebut, maka hipotesis yang diajukan dalam penelitian ini adalah:

$\mathbf{H}_{3}$ : Price to Book Value (PBV) berpengaruh positif dan signifikan terhadap return saham perusahaan sektor perkebunan yang terdaftar di Bursa Efek Indonesia.

d. Pengaruh Net Profit Margin (NPM) Terhadap Return Saham

Net Profit Margin merupakan perbandingan antara laba setelah pajak (EAT) dengan penjualan. Net Profit Margin termasuk dalam salah satu rasio profitabilitas. Rasio ini digunakan untuk mengukur rupiah laba yang dihasilkan oleh setiap penjualan. Teori ini didukung oleh penelitian yang dilakukan oleh Affinanda (2015) menunjukkan bahwa Net Profit Margin (NPM) berpengaruh positif dan signifikan terhadap return saham. Hasil penelitian lain yang dilakukan oleh Wangarry \& Poputra (2015) menunjukkan bahwa NPM berpengaruh positif dan signifikan terhadap return saham. Pada penelitian yang dilakukan oleh Kariza (2017) juga menghasilkan NPM berpengaruh positif dan signifikan terhadap return saham. Berdasarkan penjelasan tersebut, maka hipotesis yang diajukan dalam penelitian ini adalah:

$\mathbf{H}_{4}$ : Net Profit Margin (NPM) berpengaruh positif dan signifikan terhadap return saham perusahaan sektor perkebunan yang terdaftar di Bursa Efek Indonesia. 


\subsection{Kerangka Pemikiran}

Berdasarkan rumusan masalah, tujuan penelitian dan landasan teori, maka kerangka pemikiran dalam penelitian ini dirumuskan sebagai berikut:

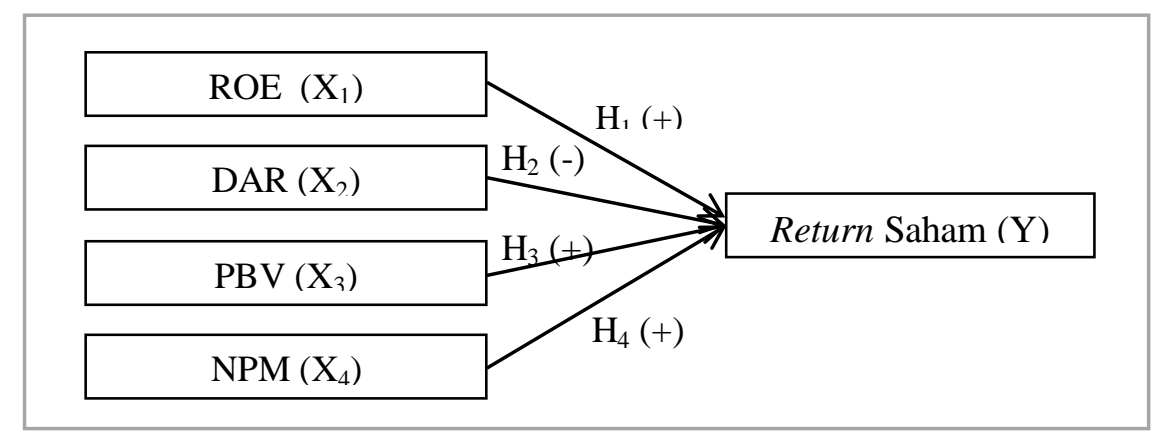

Gambar 1. Kerangka Pemikiran

\section{METODA PENELITIAN}

Populasi dalam penelitian ini adalah semua perusahaan sektor perkebunan yang terdaftar di Bursa Efek Indonesia (BEI). Sampel dalam penelitian ini diambil menggunakan teknik purposive sampling. Pemilihan sampel penelitian dilakukan dengan pertimbangan-pertimbangan atau kriteria-kriteria sebagai berikut:

1. Perusahaan sektor perkebunan yang terdaftar di Bursa Efek Indonesia yang sahamnya aktif diperdagangkan selama periode 2011-2017.

2. Perusahaan yang mempublikasikan laporan keuangan secara lengkap dan telah diaudit periode 2011-2017.

Berdasarkan kriteria-kriteria tersebut, maka jumlah sampel yang digunakan dalam penelitian ini adalah sebanyak 8 perusahaan yang disajikan pada Tabel 3 .

Tabel 3. Sampel Penelitian

\begin{tabular}{ccl}
\hline No & Kode Saham & \multicolumn{1}{c}{ Nama Emiten } \\
\hline 1. & AALI & Astra Agro Lestari Tbk. \\
\hline 2. & BWPT & Eagle High Plantations Tbk. \\
\hline 3. & GZCO & Gozco Plantation Tbk. \\
\hline 4. & LSIP & PP London Sumatera Indonesia Tbk. \\
\hline 5. & SGRO & Sampoerna Agro Tbk. \\
\hline 6. & SMAR & Sinar Mas Agro Resources and Technology Tbk. \\
\hline 7. & TBLA & Tunas Baru Lampung Tbk. \\
\hline 8. & UNSP & Bakrie Sumatera Plantation Tbk \\
\hline
\end{tabular}

Sumber: BEI, (2018)

\subsection{Variabel Penelitian}

Variabel yang digunakan dalam penelitian ini terdiri atas:

1. Variabel bebas atau independent variabel, yaitu variabel yang menjadi sebab terjadinya atau terpengaruhnya variabel terikat atau dependent. Variabel bebas atau independent dalam penelitian ini adalah:

a. Return on Equity / $\operatorname{ROE}\left(\mathrm{X}_{1}\right)$ 
Rasio Return on Equity (ROE) dihitung menurut Kasmir (2010) sebagai berikut:

$\mathrm{ROE}=\frac{\text { Earning After Interest and Tax }}{\text { Equity }}$

b. Debt Ratio atau Debt to Assets Ratio / DAR $\left(\mathrm{X}_{2}\right)$

Debt Ratio/Debt to Asset Ratio (DAR) dihitung sebagai berikut:

DAR $=\frac{\text { Total Kewajiban }}{\text { Total Aktiva }}$

c. Price to Book Value / PBV $\left(\mathrm{X}_{3}\right)$

Rasio Price to Book Value (PBV) dihitung sebagai berikut:

$\mathrm{PBV}=\frac{\text { Harga Pasar per Saham }}{\text { Nilai Buku per Saham }}$

d. Net Profit Margin / NPM $\left(\mathrm{X}_{4}\right)$

Rasio Net Profit Margin (NPM) dihitung sebagai berikut:

$\mathrm{NPM}=\frac{\text { Laba Operasi }}{\text { Penjualan }} \times 100 \%$

2. Variabel terikat atau dependent variabel (Y), yaitu variabel yang nilainya dipengaruhi oleh variabel bebas atau independent variabel. Variabel terikat atau dependent variabel dalam penelitian ini adalah return saham, yaitu harga saham saat ini dikurangi dengan harga saham periode sebelumnya dibanding dengan harga saham periode sebelumnya. Return saham dihitung sebagai berikut (Hartono, 2014) :

$\mathrm{R}_{\mathrm{it}}=\frac{\text { Pit }- \text { Pit }-1}{\text { Pit }-1} \times 100 \%$

Keterangan:

$\mathrm{R}_{\text {it }}=$ Tingkat keuntungan saham i pada periode $\mathrm{t}$

$\mathrm{P}_{\mathrm{it}}=$ Harga penutupan saham i pada periode $\mathrm{t}$ (periode penutupan/akhir)

$\mathrm{P}_{\mathrm{it}-1}=$ Harga penutupan saham i pada periode sebelumnya (awal)

\subsection{Analisis Data}

Uji instrumen data yang digunakan dalam penelitian ini menggunakan uji asumsi klasik. Uji asumsi klasik terdiri atas: uji normalitas, linieritas, multikolinieritas, autokorelasi, dan heteroskedastisitas.

Analisis regresi linier berganda digunakan untuk mengetahui pengaruh Return on Equity (ROE), Debt to Asset Ratio (DAR), Price to Book Value (PBV), dan Net Profit Margin (NPM) terhadap return saham perusahaan sektor perkebunan yang terdaftar di Bursa Efek Indonesia. Persamaan regresi linier berganda dalam penelitian ini, yaitu:

$\mathrm{Y}=\mathrm{a}+\mathrm{b}_{1} \mathrm{X}_{1}+\mathrm{b}_{2} \mathrm{X}_{2}+\mathrm{b}_{3} \mathrm{X}_{3}+\mathrm{b}_{4} \mathrm{X}_{4}+\mathrm{e}$

Keterangan:

$\mathrm{Y} \quad=$ Return saham 
$\mathrm{X}_{1} \quad=$ Return on Equity (ROE)

$\mathrm{X}_{2} \quad=$ Debt to Asset Ratio (DAR)

$\mathrm{X}_{3} \quad=$ Price to Book Value $(\mathrm{PBV})$

$\mathrm{X}_{4} \quad=$ Net Profit Margin (NPM)

Penentuan persamaan Model Regresi terbaik data panel dilakukan dengan menggunakan Uji Chow, Uji Langrance-Multiplier, dan Uji Hausmann. Uji Chow dilakukan untuk menentukan model regresi dengan membandingkan model common effect dan fixed effect yang dilihat melalui probabilitas Chi-Square keduanya. Hasil Uji Chow terpilih common effect maka diteruskan dengan Uji Langrance-Multiplier untuk memilih model common effect dan random effect. Apabila Hasil Uji Chow terpilih fixed effect maka diteruskan dengan Uji Hausmann untuk memilih model fixed effect dan random effect.

\section{HASIL PENELITIAN DAN PEMBAHASAN}

Uji statisitik deskriptif menunjukkan aspek nilai minimum, maksimal, rata-rata (mean), standard deviasi dari masing-masing variabel yang dipakai dalam penelitian. Hasil uji statistik dapat dilihat pada Tabel 4.

Tabel 4. Hasil Uji Statistik Deskriptif

\begin{tabular}{cccccc}
\hline & RETURN_SAHAM & DAR & NPM & PBV & ROE \\
\hline Mean & $-0,026352$ & 0,509817 & $-0,028576$ & 1,599739 & $-1,777628$ \\
\hline Median & $-0,089390$ & 0,540803 & 0,093786 & 1,358052 & 0,099780 \\
\hline Maximum & 2,260000 & 0,950000 & 0,363070 & 4,255599 & 1,352200 \\
\hline Minimum & $-0,824903$ & 0,140232 & $-2,840200$ & 0,140943 & $-65,29000$ \\
\hline Std, Dev, & 0,470042 & 0,202820 & 0,485722 & 1,085661 & 10,20436 \\
\hline Observations & 56 & 56 & 56 & 56 & 56 \\
\hline
\end{tabular}

Berdasarkan pada Tabel 4, hasil deskriptif menunjukkan bahwa rata-rata return saham dari 8 sampel perusahaan perbankan periode 2011-2017 adalah -0,026352. Nilai minimum return saham oleh LSIP Tahun 2011 Sebesar -0,824903. Sedangkan nilai maksimum return saham oleh UNSP Tahun 2017 sebesar 2,260000. standard deviasi return saham menunjukkan 0,470042. Angka tersebut melebihi nilai rata-rata sehingga variabel berikut masih menunjukkan kesenjangan yang besar antara data maksimum dan minimum.

Pada variabel DAR, hasil deskriptif menunjukkan rata-rata DAR dari 8 sampel perusahaan periode 2011-2017 adalah 0,50981. Nilai minimum DAR oleh LSIP Tahun 2012 sebesar 0,14032. Sedangkan nilai maksimum DAR oleh UNSP Tahun 2017 sebesar 9,5000. Standar deviasi return saham menunjukkan 0,202820. Angka tersebut kurang dari nilai rata-rata sehingga variabel berikut masih menunjukkan kesenjangan yang kecil antara data maksimum dan minimum.

Pada variabel NPM menunjukkan rata-rata NPM dari 8 sampel perusahaan periode 20112017 adalah -0,028576. Nilai minimum NPM oleh GZCO Tahun 2016 Sebesar -2,840200. Nilai maksimum NPM oleh BWPT Tahun 2011 sebesar 0,363070. Standar deviasi return saham 
menunjukkan 0,485722. Angka tersebut melebihi nilai rata-rata sehingga variabel berikut masih menunjukkan kesenjangan yang besar antara data maksimum dan minimum.

Pada variabel PBV, hasil deskriptif menunjukkan rata-rata PBV dari 8 sampel perusahaan periode 2011-2017 adalah 1,599739. Nilai minimum PBV oleh UNSP Tahun 2013 Sebesar 0,140943. Sedangkan nilai maksimum PBV oleh BWPT Tahun 2012 sebesar 4,255599. Standar deviasi return saham menunjukkan 1,085661. Angka tersebut kurang dari nilai rata-rata sehingga variabel berikut masih menunjukkan kesenjangan yang kecil antara data maksimum dan minimum.

Pada variabel ROE, hasil deskriptif menunjukkan rata-rata ROE dari 8 sampel perusahaan periode 2011-2017 adalah -1,777628. Nilai minimum DAR oleh LSIP Tahun 2012 sebesar -65,29000. Sedangkan nilai maksimum DAR oleh UNSP Tahun 2017 sebesar 1,352200. Standar deviasi return saham menunjukkan 10,2406. Angka tersebut melebihi nilai rata-rata sehingga variabel berikut masih menunjukkan kesenjangan yang besar antara data maksimum dan minimum.

\subsection{Hasil Analisis Data}

Analisis data penelitian terdiri atas 2 bagian yaitu: uji instrumen data dan analisis regresi linier berganda. Hasil analisis data dijelaskan sebagai berikut:

1. Uji Instrumen Data

Uji instrumen data menggunakan uji asumsi klasik dengan hasil sebagai berikut:

a. Uji Normalitas

Hasil uji normalitas yang diperoleh memiliki nilai Jarque-Bera sebesar 4,028203 dengan nilai probabilitas 0,133440 berada di atas 0,05 sehingga dari olahan data ini, model regresi dapat dikatakan normal dan memenuhi persyaratan uji asumsi klasik.

b. Uji Linieritas

Pengujian Linieritas dilakukan dengan metode Ramsye RESET Test. Hasil analisis terlihat bahwa nilai probabilitas F-Statistic adalah 0,9822 dan lebih besar dari 0,05 sehingga dapat disimpulkan bahwa model regresi telah memenuhi asumsi linieritas.

c. Uji Heterokedastisitas

Heterokedastisitas suatu data dengan melihat nilai probability Obs*R-Squared pada uji White. Jika nilai probability melebihi tingkat alpha 0,05 maka suatu data dapat dikatakan terbebas dari heterokedastisitas atau sebaliknya. Hasil uji White pada data penelitian menunjukkan bahwa nilai probabilitas Obs* $R$-Squared variabel independen sebesar 0,1219 . Nilai tersebut di atas 0,05 sehingga dapat disimpulkan bahwa variabelvariabel independen dalam penelitian ini tidak terjadi heterokedastisitas.

d. Uji Autokorelasi

Pengujian autokorelasi dapat dilihat dari nilai Durbin-Watson. Model regresi yang baik adalah model yang terbebas dari autokorelasi antar variabel. Dasar pengambilan keputusan adalah nilai Durbin-Watson yang berada pada kisaran 1,5 sampai 2,46 merujuk pada Ghozali (2006). Hasil pengujian gejala autokorelasi adalah nilai DurbinWatson mencapai 2,227178 sehingga model regresi dipastikan terbebas dari autokorelasi. 
e. Uji Multikolinieritas

Uji multikolinieritas menggunakan Variance Inflation Factor (VIF) yang tersedia untuk mendeteksi ada atau tidaknya multikolonieritas di dalam model regresi. Jika nilai berada di bawah 10 maka tidak terdapat korelasi antar variabel bebas yang satu dengan yang lainnya atau sebaliknya. Hasil analisis data menunjukkan bahwa nilai VIF yaitu: 1,493 (DAR), 1,298 (NPM), 1,264 (PBV) dan 1,275 (ROE). Nilai VIF seluruh variabel kurang dari 10 sehingga dapat disimpulkan bahwa variabel-variabel independen dalam penelitian ini tidak terjadi korelasi

2. Analisis Regresi Linier Berganda

Pemilihan model regresi linier berganda menggunakan uji Chow yaitu dengan memilih model common effect dan fixed effect. Uji Chow merupakan analisis perbandingan model common effect dan fixed effect dengan melihat nilai probabilitas Chi-Square. Hasil analisis uji Chow menghasilkan nilai probabilitas Chi-Square sebesar 0,4452. Hasil ini dapat dilihat pada Tabel 5. Nilai probabilitas Chi-Square berada di atas 0,05 maka model common effect yang terpilih.

\section{Tabel 5. Uji Chow}

Redundant Fixed Effects Tests

\begin{tabular}{lccc}
\hline Effects Test & Statistic & d.f. & Prob. \\
\hline Cross-section F & 0,817242 & $(7,44)$ & 0,5781 \\
Cross-section Chi-square & 6,844969 & 7 & 0,4452 \\
\hline
\end{tabular}

Berdasarkan Uji Chow, uji selanjutnya adalah Uji Langrange-Multiplier untuk menentukan model regresi dengan membandingkan common effect dan random effect yang dilihat melalui probabilitas Breusch-Pagan. Hasil uji Langrange-Multiplier menunjukkan bahwa probabilitas bernilai 0,5239. Karena nilai probabilitas Breusch-Pagan berada di atas 0,05 maka model common effect yang terpilih. Dari hasil ketiga pengujian model regresi, model regresi yang terpilih dalam penelitian ini adalah menggunakan common effect. Model common effect dapat dilihat pada Tabel 7.

\section{Tabel 6. Uji Langrange-Multiplier}

Lagrange Multiplier Tests for Random Effects

\begin{tabular}{lcll}
\hline & \multicolumn{3}{c}{ Test Hypothesis } \\
& Cross-section & Time & Both \\
\hline Breusch-Pagan & 0,406112 & 1,786804 & 2,192916 \\
& $(0,5239)$ & $(0,1813)$ & $(0,1386)$ \\
Honda & $-0,637269$ & 1,336714 & 0,494582 \\
& -- & $(0,0907)$ & $(0,3104)$ \\
King-Wu & $-0,637269$ & 1,336714 & 0,547941 \\
& -- & $(0,0907)$ & $(0,2919)$ \\
Standardized Honda & $-0,078184$ & 1,668409 & $-2,200955$ \\
& -- & $(0,0476)$ & \\
Standardized King-Wu & $-0,078184$ & 1,668409 & $-2,131777$ \\
& -- & $(0,0476)$ & -- \\
Gourierioux, et al, & -- & -- & 1,786804 \\
& & & $(>=0.10)$ \\
\hline
\end{tabular}


Tabel 7. Model Common Effect

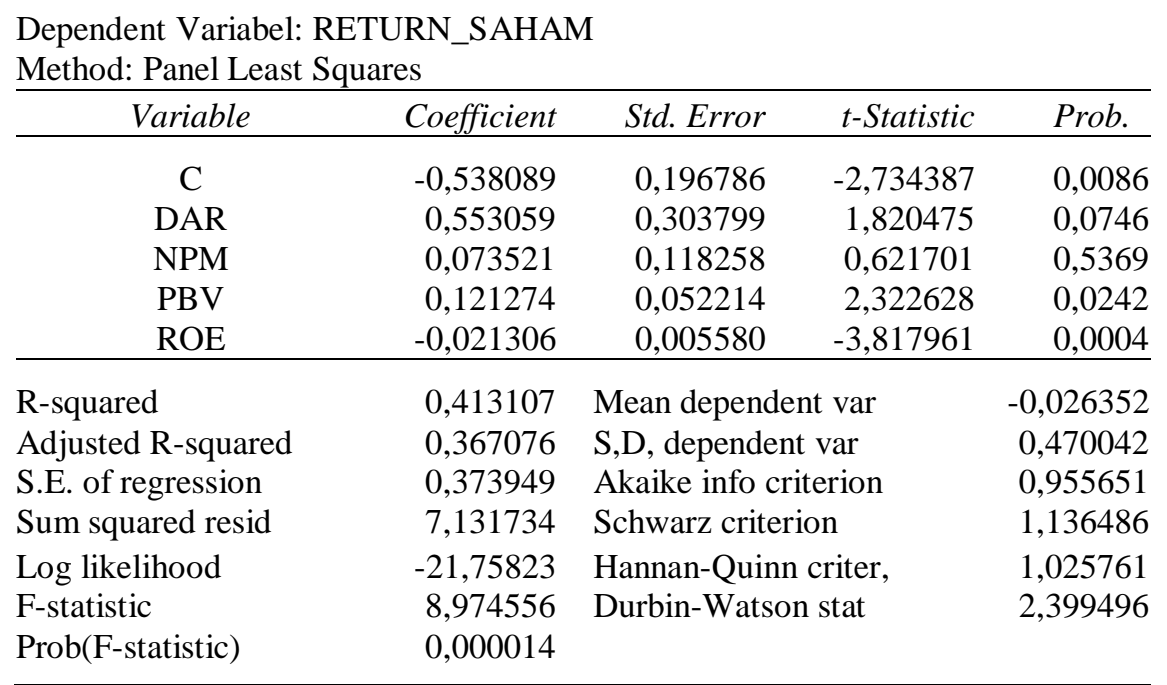

Model regresi linier berganda sebagai berikut:

$Y=-0,538089+-0,021306 X_{1}+0,553059 X_{2}+0,121274 X_{3}+0,073521 X_{4}+e$

Model regresi linier berganda menunjukkan koefisien yaitu: ROE $\left(\mathrm{X}_{1}\right)$ sebesar -0,021306, DAR $\left(\mathrm{X}_{2}\right)$ sebesar 0,553059, PBV $\left(\mathrm{X}_{3}\right)$ sebesar 0,121274, dan NPM $\left(\mathrm{X}_{4}\right)$ sebesar 0,073521. ROE bernilai negatif sehingga kenaikannya akan mengurangi return saham. DAR, PBV dan NPM bernilai positif sehingga kenaikannya akan menambah return saham.

\subsection{Uji Hipotesis}

Uji simultan atau disebut juga uji $\mathrm{F}$ berganda bertujuan untuk mengetahui kemampuan seluruh variabel independen dalam penelitian secara bersama-sama dapat mempengaruhi variabel dependen. Pengujian dilakukan dengan menggunakan nilai probabilitas $\mathrm{F}$ ( $F$-statistic) dengan significance level $(\alpha)$ sebesar 0,05 . Apabila nilai $F$-statistic $<0,05$ maka seluruh variabel independen secara bersama-sama berpengaruh terhadap variabel dependen dan sebailknya. Berdasarkan hasil uji F dari model Fixed Effect pada Tabel 7, menunjukkan bahwa nilai Fstatistic sebesar 0,000014 dan lebih kecil dari significance level $(\alpha=0,05)$ maka DAR, NPM, PBV dan ROE secara bersama-sama berpengaruh terhadap Return Saham.

Koefisien Determinasi menguji seberapa besar pengaruh variabel independen dapat mempengaruhi variabel dependen. Uji ini dilakukan dengan melihat hasil nilai dari Adjusted $R$ squared. Semakin kecil nilai Adjusted $R$-squared maka kemampuan variabel independen menjelaskan variabel dependen lemah atau sebaliknya jika nilai Adjusted $R$-squared besar maka kemampuan variabel independen menjelaskan variabel dependen dinyatakan kuat. Hasil perhitungan pada Tabel 7 menunjukkan nilai $R$-Squared sebesar 0,367076 yang berarti menunjukkan bahwa kemampuan model yang terdiri dari 4 variabel yaitu DAR, NPM, PBV, dan ROE dalam menjelaskan pengaruh terhadap return saham sebesar $36,7 \%$, sedangkan sisanya yaitu sebesar 63,3\% dijelaskan oleh variabel lain yang tidak dimasukan dalam model.

Uji $t$ digunakan untuk menguji hipotesis penelitian $\left(\mathbf{H}_{\mathbf{1}}, \mathbf{H}_{\mathbf{2}}, \mathbf{H}_{\mathbf{3}}\right.$, dan $\left.\mathbf{H}_{4}\right)$. Dasar pengambilan keputusan pada uji $\mathrm{t}$ adalah apabila nilai Probabilitas $<0,05$ dan sama arah maka 
hipotesis diterima dan apabila nilai Probabilitas > 0,05 maka hipotesis ditolak. Hasil uji t pada masing-masing variabel independen $\left(\mathrm{X}_{1}, \mathrm{X}_{2}, \mathrm{X}_{3}\right.$ dan $\left.\mathrm{X}_{4}\right)$ dalam penelitian ini dapat dijelaskan sebagai berikut:

$\mathbf{H}_{1}$ : Return on Equity (ROE) berpengaruh positif dan signifikan terhadap return saham perusahaan sektor perkebunan yang terdaftar di Bursa Efek Indonesia.

Berdasarkan Tabel 7 pada persamaan model common effect, dapat diketahui bahwa nilai Probabilitas ROE terhadap return saham sebesar 0,0004 dengan nilai $t_{\text {hitung }}$ bernilai negatif sebesar -3,818796. Hasil analisis menunjukkan bahwa nilai Probabilitas pada variabel ROE lebih kecil dari 0,05 (Prob. $<0,05$ ) dan tidak sama arah (negatif) maka $\mathrm{H}_{1}$ ditolak. Hasil uji hipotesis menunjukkan bahwa Return on Equity (ROE) berpengaruh negatif dan signifikan terhadap return saham perusahaan sektor perkebunan yang terdaftar di Bursa Efek Indonesia.

$\mathbf{H}_{2}$ : Debt to Assets Ratio (DAR) berpengaruh negatif dan signifikan terhadap return saham perusahaan sektor perkebunan yang terdaftar di Bursa Efek Indonesia.

Berdasarkan Tabel 7 pada persamaan model common effect, dapat diketahui bahwa nilai Probabilitas DAR terhadap return saham sebesar 0,0746 dengan nilai $t_{\text {hitung }}$ bernilai positif sebesar 1,820475. Hasil analisis menunjukkan bahwa nilai Probabilitas pada variabel DAR lebih besar dari 0,05 (Prob. > 0,05) dan tidak sama arah (positif) maka $\mathrm{H}_{2}$ ditolak. Hasil uji hipotesis menunjukkan bahwa Debt to Assets Ratio (DAR) tidak berpengaruh signifikan terhadap return saham perusahaan sektor perkebunan yang terdaftar di Bursa Efek Indonesia.

$\mathbf{H}_{3}$ : Price to Book Value (PBV) berpengaruh positif dan signifikan terhadap return saham perusahaan sektor perkebunan yang terdaftar di Bursa Efek Indonesia.

Berdasarkan Tabel 7 pada persamaan model common effect, dapat diketahui bahwa nilai Probabilitas PBV terhadap return saham sebesar 0,0242 dengan nilai $t_{\text {hitung }}$ bernilai positif sebesar 2,322628. Hasil analisis menunjukkan bahwa nilai Probabilitas pada variabel PBV lebih kecil dari 0,05 (Prob. < 0,05) dan sama arah (positif) maka $\mathrm{H}_{3}$ diterima. Hasil uji hipotesis menunjukkan bahwa Return on Equity (PBV) berpengaruh positif dan signifikan terhadap return saham perusahaan sektor perkebunan yang terdaftar di Bursa Efek Indonesia.

$\mathbf{H}_{4}$ : Net Profit Margin (NPM) berpengaruh positif dan signifikan terhadap return saham perusahaan sektor perkebunan yang terdaftar di Bursa Efek Indonesia.

Berdasarkan Tabel 7 pada persamaan model common effect, dapat diketahui bahwa nilai Probabilitas PBV terhadap return saham sebesar 0,5396 dengan nilai $t_{\text {hitung }}$ bernilai positif sebesar 0,621701. Hasil analisis menunjukkan bahwa nilai Probabilitas pada variabel PBV lebih besar dari 0,05 (Prob. > 0,05) dan sama arah (positif) maka $\mathrm{H}_{4}$ ditolak. Hasil uji hipotesis menunjukkan bahwa Return on Equity (PBV) tidak berpengaruh signifikan terhadap return saham perusahaan sektor perkebunan yang terdaftar di Bursa Efek Indonesia. 


\subsection{Pembahasan}

Berdasarkan hasil uji hipotesis maka dapat dijelaskan sebagai berikut:

1. Pengaruh ROE terhadap Return Saham

Hasil penelitian ini menunjukkan bahwa Return on Equity (ROE) memiliki pengaruh positif dan tidak signifikan terhadap return saham. Ini dibuktikan dari koefisien regresi ROE yang bernilai negatif dan hasil uji pengaruh parsial (uji t) yang menunjukkan nilai probabilitas yang berada di bawah $0,05 \%(0,0004)$ sehingga hipotesis alternatif yang menyatakan PBV berpengaruh signifikan terhadap return saham diterima. Hal ini terlihat dari kondisi sampel yang rata-rata memiliki ROE negatif dan sejalan dengan kondisi variabel return saham perusahaan perkebunan. Return on Equity (ROE) menggambarkan sampai sejauh mana kemampuan perusahaan dalam menghasilkan laba yang tersedia bagi pemegang saham. Semakin tinggi nilai ROE, maka semakin efisien perusahaan dalam menggunakan modal sendiri untuk menghasilkan laba bagi perusahaan. Oleh karena itu, pemanfaatan laba yang efisien akan memberikan harapan naiknya return saham yang dimilikinya.

Hasil penelitian ini sejalan dengan penelitian yang dilakukan oleh Affinanda (2015) bahwa ROE memiliki pengaruh positif terhadap return saham. Penelitian dengan hasil yang sama juga dilakukan oleh Erwin (2013) dan Beny \& Mendari (2011) bahwa Return on Equity (ROE) memiliki pengaruh signifikan terhadap return saham.

\section{Pengaruh DAR Terhadap Return Saham}

Hasil penelitian ini menunjukkan bahwa Debt to Asset Ratio (DAR) memiliki pengaruh positif dan signifikan terhadap return saham. Ini dibuktikan dari koefisien regresi DAR yang bernilai positif dan hasil uji pengaruh parsial (uji t) yang menunjukkan nilai probabilitas yang berada di atas $0,05 \%(0,0746)$. Hasil koefisien regresi berikut dikarenakan strategi perusahaan dalam pendanaan terkait dengan teori struktur modal yaitu pecking order theory yang menyimpulkan bahwa manajemen perusahaan memilih untuk menggunakan biaya modal yang hanya berasal dari internal perusahaan berupa laba ditahan. Sedangkan hubungan antara kedua variabel diduga belum berpengaruh signifikan karena kondisi DAR yang cenderung tinggi justru memiliki return saham yang negatif. Kondisi berikut terlihat dari rata-rata return saham mengandung nilai-nilai rata-rata yang cenderung negatif yakni -0,026352. Sedangkan variabel DAR memiliki nilai rata-rata positif yang cukup tinggi yaitu 0,509817. Hasil penelitian ini tidak sejalan dengan penelitian yang dilakukan Santri (2012) bahwa Debt to Asset Ratio (DAR) memiliki pengaruh negatif dan signifikan terhadap return saham. Sementara pada penelitian Carolin (2014) menunjukkan Debt to Asset Ratio (DAR) memiliki pengaruh negatif tetapi tidak signifikan terhadap return saham.

\section{Pengaruh PBV terhadap Return Saham}

Hasil penelitian ini menunjukkan bahwa Price to Book Value (PBV) memiliki pengaruh positif dan signifikan terhadap return saham. Ini dibuktikan dari koefisien regresi PBV yang bernilai positif dan hasil uji pengaruh parsial (uji t) yang menunjukkan nilai probabilitas yang berada di bawah $0,05 \%(0,0242)$ sehingga hipotesis alternatif yang menyatakan PBV berpengaruh signifikan terhadap return saham diterima. Rasio PBV menggambarkan seberapa besar pasar menghargai nilai buku saham suatu perusahaan. Semakin tinggi rasio ini akan 
memberikan gambaran bahwa semakin tingginya harga saham perusahaan menunjukkan semakin baiknya kinerja perusahaan, sehingga dapat memberikan tingkat return yang lebih baik di masa yang akan datang. Hal ini terlihat dari kondisi sampel penelitian khususnya variabel PBV yang cenderung memiliki nilai rata-rata yang rendah yaitu berkisar 1.599379 yang sejalan dengan return saham perkebunan yang nilainya justru negatif.

Hasil penelitian ini berbeda dengan penelitian yang dilakukan oleh Putri (2012) bahwa Price to Book Value (PBV) berpengaruh positif dan signifikan terhadap return saham. Hasil yang sama penelitian yang dilakukan Kamaludin \& Indriani (2012)bahwa PBV berpengaruh positif dan signifikan terhadap return saham. Demikian pula dengan penelitian yang dilakukan oleh Akbar \& Herianingrum (2015) bahwa PBV berpengaruh positif dan signifikan terhadap return saham.

\section{Pengaruh NPM terhadap Return Saham}

Hasil penelitian ini menunjukkan bahwa Net Profit Margin (NPM) memiliki pengaruh positif dan tidak signifikan terhadap return saham. Ini dibuktikan dari koefisien regresi NPM yang bernilai positif dan hasil uji pengaruh parsial (uji t) yang menunjukkan nilai probabilitas yang berada di atas $0,05 \%$ (0,5396), sehingga hipotesis nol yang menyatakan NPM tidak berpengaruh signifikan terhadap return saham diterima. Pengaruh berikut dikarenakan banyaknya sampel penelitian ini yang cenderung memiliki nilai NPM yang tinggi namun tidak disertai dengan nilai return yang positif. Sehingga hasil dari regresi tidak sejalan dengan teori semestinya yang menyatakan bahwa semakin tingginya rasio net profit margin, maka akan memberikan gambaran terhadap semakin produktifnya suatu perusahaan, sehingga perusahaan dinilai mampu memperoleh laba dan mampu memberikan hasil investasi yang memuaskan bagi investor.

Hasil penelitian ini tidak sejalan dengan penelitian yang dilakukan oleh (Affinanda, 2015) bahwa NPM tidak berpengaruh signifikan terhadap return saham. Demikian juga dengan penelitian yang dilakukan oleh Wangarry \& Poputra (2015) dan (Kariza, 2017) bahwa NPM tidak berpengaruh positif dan signifikan terhadap return saham..

\section{SIMPULAN}

Berdasarkan hasil penelitian dan pembahasan pada perusahaan sektor perkebunan yang terdaftar di Bursa Efek Indonesia periode 2011-2017, maka dapat disimpulkan sebagai berikut: 1) Return on Equity (ROE) berpengaruh negatif terhadap return saham, 2) Debt to Assets Ratio (DAR) tidak berpengaruh positif terhadap return saham, 3) Price to Book Value (PBV) berpengaruh positif terhadap return saham, 4) Net Profit Margin (NPM) tidak berpengaruh positif terhadap return saham.

Penelitian berikutnya diharapkan dapat menggunakan rasio keuangan perusahaan yang berbeda terutama yang belum dimasukkan dalam model penelitian ini karena rasio PBV, dan NPM terbukti tidak berpengaruh signifikan terhadap return saham, sedangkan ROE dan DAR mempunyai pengaruh signifikan namun berkebalikan arah. Oleh karena itu, berdasarkan hasil uji determinasi maka masih ada rasio keuangan lainnya yang berpengaruh terhadap return saham. 
Manfaat teoritis berdasarkan hasil penelitian adalah adanya hasil temuan baru yang berbeda dengan penelitian sebelumnya. Adanya hasil yang berbeda memberikan implikasi bahwa secara teori akan memberikan tambahan referensi bagi penelitian selanjutnya sehingga mendukung relevansi teori baru.

Hasil penelitian akan memberikan referensi praktis bagi pelaku usaha bahwa temuan yang ada mengalami perkembangan. Penerapan kebijakan perusahaan memperhatikan perubahan kondisi ekonomi makro dan mikro suatu negara.

\section{DAFTAR PUSTAKA}

Abor, J. (2007). Debt policy and performance of SMEs Evidence from Ghanaian and South African firms. The Journal of Risk Finance, 8(4), 364-379. https://doi.org/10.1108/15265940710777315

Affinanda, A. (2015). Analisis Pengaruh Rasio Keuangan Terhadap Return Saham Perusahaan Dalam Indeks LQ 45 Tahun 2010-2013. (Tesis yang tidak dipublikasikan), Universitas Diponegoro, Indonesia.

Akbar, R., \& Herianingrum, S. (2015). Analisis Pengaruh DER, PBV, dan PER Terhadap Return Saham Perusahaan Manufaktur Yang Terdaftar di Bursa Efek Indonesia Periode 2008 2012 (Studi Kasus Pada Perusahaan Dalam Kategori Consumer Goods Industry, Food And Beverages, Tobacco Manufactur, Papper). Jurnal Ekonomi Syariah Teori Dan Terapan, 2(9), 698-713. https://doi.org/10.1017/CBO9781107415324.004

BEI. (2018). Data Keuangan. Retrieved June 11, 2018, from www.idx.co.id

Beny, \& Mendari, A. S. (2011). Pengaruh Value Added Statement, ROA, ROE, Dan Operating Cash Flow Terhadap Return Saham Pada Perusahaan Yang Tergabung Di BEI. Widya Warta, 1, 151-166.

Carlo, M. A. (2014). Pengaruh Return On Equity, Dividend Payout Ratio, Dan Price to Earning Ratio pada Return Saham. E-Jurnal Akuntansi Universitas Udayana, 7(1), 151-164. https://doi.org/10.1017/CBO9781107415324.004

Carolin, M. (2014). Analisis Return On Equity (ROE), Debt To Assets Ratio (DAR), Dan Price Book Value (PBV) Terhadap Return Saham Perusahaan Sektor Real Estate Dan Property Yang Terdaftar Di Bursa Efek Indonesia Periode 2009-2012. Jurnal Manajemen Update, 3(4). Retrieved from http://jurnal.untan.ac.id/index.php/ejmfe/article/view/7934

D’Antoni, J. M. D., \& Detre, J. D. (2016). Are Agribusiness Stocks An Investor Safe Haven? Agricultural Finance Review, 74(4), 522-538. https://doi.org/10.1108/AFR-06-2013-0027

Djokoto, J. G., Srofenyoh, F. Y., \& Gidiglo, K. (2014). Domestic and Foreign Direct Investment in Ghanaian Agriculture. Agricultural Finance Review, 74(3), 427-440. https://doi.org/10.1108/AFR-09-2013-0035

Erwin. (2013). Pengaruh Return On Assets (ROA), Return On Equity (ROE), Dan Debt to Equity Ratio (DER) Terhadap Return Saham Pada Perusahaan Makanan dan Minuman Yang Terdaftar Di Bursa Efek Indonesia. Jurnal Manajemen Update, 2(2). Retrieved from http://jurnal.untan.ac.id/index.php/ejmfe/article/view/2263 
Ghozali, I. (2006). Aplikasi Analisis Multivariate Dengan Program SPSS. Semarang: Universitas Diponegoro.

Hadi, N. (2015). Pasar Modal. Yogyakarta: Graha Ilmu.

Hartono, J. (2014). Teori Portofolio dan Analisis Investasi Edisi Kesembilan. Yogyakarta: BPFE-Yogyakarta.

Heniwati, E., \& Yani, E. (2011). Pengaruh Karakteristik Perusahaan Terhadap Kelengkapan Pengungkapan Pada Laporan Keuangan Tahunan Perusahaan Properti Dan Real Estate. Jurnal Ekonomi Bisnis Dan Kewirausahaan, 2(1), 28-52. Retrieved from http://jurnal.untan.ac.id/index.php/JJ/article/view/700/696

Hobbs, J., Schaupp, L. C., \& Gingrich, J. (2016). Terrorism, Militarism, and Stock Returns. Journal of Financial Crime, 23(1), 70-86. https://doi.org/10.1108/JFC-01-2015-0002

Horne, J. C. Van, \& Wachowicz, J. M. (2008). Fundamentals of Financial Management (13th Edition). London: Pearson Education Limited.

Indriani, T. (2014). Analisis Pengaruh DER, PBV, Dan PER Terhadap Return Saham Perusahaan Manufaktur Yang Terdaftar Di Bursa Efek Indonesia Periode 2008 - 2012 (Studi Kasus Pada Perusahaan Dalam Kategori Consumer Goods Industry, Food And Beverages, Tobacco Manufactur, Papper). (Skripsi yang tidak dipublikasikan), Universitas Bengkulu, Indonesia.

Kadri, M. H., Aziz, R. A., \& Ibrahim, M. K. (2009). Value Relevance of Book Value and Earnings: Evidence from Two Different Financial Reporting Regimes. Journal of Financial Reporting and Accounting, 7(1), 1-16. Retrieved from https://doi.org/10.1108/19852510980000638

Kamaludin, \& Indriani, R. (2012). Manajemen Keuangan: Konsep Dasar dan Penerapannya. Bandung: CV Mandar baru.

Kariza, C. I. (2017). Pengaruh Suku Bunga, Earning Per Share (EPS), Net Profit Margin (NPM), Price To Book Value (PBV) Terhadap Return Saham (Studi Empiris Pada Perusahaan Sektor Properti, Real Estate, dan Konstrusi Bangunan di Bursa Efek Indonesia). Jurnal Manajemen Dan Bisnis, l(4). $\quad$ Retrieved from http://jurnal.untan.ac.id/index.php/jmdb/article/view/21081

Kasmir. (2010). Pengantar Manajemen Keuangan. Jakarta: Kencana.

Mishra, A. K., Harris, J. M., Erickson, K. W., Hallahan, C., \& Detre, J. D. (2012). Drivers of agricultural profitability in the USA. Agricultural Finance Review Drivers, 72(3), 325-340. https://doi.org/10.1108/00021461211277213

Mollick, A., \& Nguyen, K. H. (2015). U . S . Oil Company Stock Returns and Currency Fluctuations. Managerial Finance, 41(9), 974-994. https://doi.org/10.1108/MF-02-20140029

Nunoo, J., \& Acheampong, B. N. (2014). Protecting Financial Investment: Agriculture Insurance in Ghana. Agricultural Finance Review, 74(2), 236-247. https://doi.org/10.1108/AFR-102013-0037 
Putri, A. A. B. (2012). Analisis pengaruh ROA, EPS, NPM, DER dan PBV terhadap return saham. Diponegoro Business Review, 1, 1-11.

Santri, Y. D. (2012). Pengaruh Debt to Asset Ratio (DAR) dan Debt to Equity Ratio (DER) terhadap Return Saham Melalui Net Profit Margin (NPM) pada Perusahaan Otomotif dan Komponen yang Listing di Bursa Efek Indonesia periode 2009-2011. (Skripsi yang tidak dipublikasikan), Universitas Negeri Malang, Indonesia.

Sari, R. L. (2016). Pengaruh NPM, ROE, EPS Terhadap Return Saham Pada Perusahaan Farmasi Di BEI. Jurnal Ilmu Dan Riset Manajemen, 5(12), 1-18.

Tandelilin, E. (2010). Portofolio dan Investasi Teori dan Aplikasi. Yogyakarta: Penerbit Kanisius.

Wangarry, A. R., \& Poputra, A. T. (2015). Pengaruh Tingkat Return on Investment ( ROI ), Net Profit Margin ( NPM ), Dan Debt To Equity Ratio ( DER ) Terhadap Harga Saham Perbankan Di Bursa Efek Indonesia ( BEI ). Jurnal EMBA: Jurnal Riset Ekonomi, Manajemen, Bisnis Dan Akuntansi, 3(4), 470-477. Retrieved from https://ejournal.unsrat.ac.id/index.php/emba/article/view/10938/10527 